\title{
EFFECT OF THE PREVAILING AIR TEMPERATURE ON MORTALITY
}

\author{
BY \\ R. K. MACPHERSON*, F. OFNER $\dagger$, AND J. A. WELCH* \\ From the School of Public Health and Tropical Medicine, University of Sydney*, and \\ Lidcombe Hospitalt, Lidcombe, New South Wales, Australia
}

It would be generally agreed that the weather is not without effect upon mortality and further that, in this respect, its most important component is the prevailing temperature. For example, it has been shown (Russell, 1924, 1926) that part at least of the increase in mortality associated with the occurrence of fog is, in fact, attributable not to the fog per se but to the associated low air temperatures, and it is significant that the disastrous London "smog" of December, 1952 (Logan, 1953) was accompanied by bitterly cold weather. Even in the State of New South Wales, where mild winters are experienced, more deaths occur in winter than in summer.

However, when a more precise assessment of the effect of temperature on mortality is attempted, the problem arises of associating each death with its appropriate air temperature. Daily returns of deaths with respect to their occurrence, as distinct from their registration, may not be available, and weekly or monthly returns cannot be used in association with average weekly or monthly temperatures, as these mean values may obscure significant extremes. Again, large differences in temperature can exist within even small geographical areas, so that published meteorological data can be applied with confidence only to a restricted area adjacent to the station at which the observations were made. This, in turn, restricts the number of deaths to which the information on the temperature can be applied, so that these may, in consequence, prove too few to provide reliable conclusions.

In the investigation reported here, an attempt was made to overcome these difficulties by making systematic daily observations of the temperature in an area of concentrated mortality in which details of the deaths occurring each day were readily available, thus ensuring both a reliable measure of the temperature with which each death was associated and an adequate number of deaths for statistical purposes.
The results confirm that a relation exists between the mortality and the temperature prevailing on the day of death, but that it is modified by such factors as age and the temperature of the preceding day.

\section{MATERIAL AND Methods}

The investigation was begun on October 1, 1962, and is continuing, but the results described in this paper are restricted to the calendar year January 1 to December 31, 1963.

The Population.-The population studied consisted of the inmates of a hospital and home for the aged and chronically ill situated in an outer suburb of Sydney, New South Wales. The institution is in open country to the west of the metropolitan area, approximately at sea level and 14 miles from the coast. As beds became vacant, the population was replenished from a waiting list, so that little change was to be expected either in its nature or in its size throughout the year.

Air Temperature. - The air (dry-bulb) temperature was measured in the shade of a deep verandah adjacent to a typical ward at 9.0 a.m. and 3.0 p.m. each day. The associated humidity and barometric pressure were also recorded.

Considerable thought was given to the appropriate temperature to associate with each death. The 3.0 p.m. temperature is a close approximation to the daily maximum temperature and, therefore, would seem to be the temperature of choice for assessing the effect of high environmental temperatures. On the other hand the $9.0 \mathrm{a} . \mathrm{m}$. temperature, approaching as it does more closely to the minimum temperature, would seem to provide a better measure of cold stress. However, it was finally concluded that the 3.0 p.m. ambient temperature provided the best available single measure of the prevailing thermal 
environment, and it is used as such throughout this paper.

Records of Deaths.-The number of deaths which occurred each day, together with such details as the age of the deceased, was obtained from the hospital records on the next succeeding day.

\section{RESUltS}

\section{Prevailing Temperature}

The mean monthly 3.0 p.m. temperature at the institution is set out in Table I. Although this provides useful information on the nature of the climate, it gives little indication of the temperature occurring on any one day, or of the range of temperatures encountered. The highest 3.0 p.m. temperature recorded was $96^{\circ} \mathrm{F}$. and the lowest $48^{\circ} \mathrm{F}$.; there were six occasions when the temperature was below $50^{\circ} \mathrm{F}$. and nine occasions when it was above $89^{\circ} \mathrm{F}$.

TABLE I

MEAN MONTHLY 3.0 P.M. TEMPERATURES RECORDED AT THE INSTITUTION AND AT THE OFFICIAL METEORAT THOGICAL STATION FOR THE CITY OF SYDNEY

\begin{tabular}{l|c|c}
\hline \multirow{2}{*}{ Month } & \multicolumn{2}{|c}{ Temperature ( ${ }^{\circ} \mathbf{F}$ ) } \\
\cline { 2 - 3 } & Institution & City of Sydney \\
\hline & & \\
January & $80 \cdot 3^{\circ}$ & $76 \cdot 4^{\circ}$ \\
February & $81 \cdot 4^{\circ}$ & $78 \cdot 0^{\circ}$ \\
March & $75 \cdot 2^{\circ}$ & $74 \cdot 5^{\circ}$ \\
April & $70 \cdot 0^{\circ}$ & $71 \cdot 3^{\circ}$ \\
May & $64 \cdot 4^{\circ}$ & $66 \cdot 2^{\circ}$ \\
June & $58 \cdot 1^{\circ}$ & $61 \cdot 1^{\circ}$ \\
July & $56 \cdot 9^{\circ}$ & $60 \cdot 3^{\circ}$ \\
August & $58 \cdot 6^{\circ}$ & $60 \cdot 5^{\circ}$ \\
September & $65 \cdot 3^{\circ}$ & $66 \cdot 4^{\circ}$ \\
October & $71 \cdot 1^{\circ}$ & $68 \cdot 5^{\circ}$ \\
November & $73 \cdot 4^{\circ}$ & $69 \cdot 3^{\circ}$ \\
December & $78 \cdot 5^{\circ}$ & $74 \cdot 9^{\circ}$ \\
\hline
\end{tabular}

By courtesy of the Commonwealth Meteorological Bureau, it was possible to compare the readings obtained at the institution with those for the metropolitan area in Sydney. The official station for the metropolitan area is on the shore of Sydney Harbour, 4 miles from the coast where it is freely exposed to the modifying effect of propinquity to the sea. The mean monthly $3.0 \mathrm{p} . \mathrm{m}$. temperatures for this station, also set out in Table I, would seem to show that, at the institution, it was warmer in summer and colder in winter but, apart from this, there was no great disparity in the weather at the two localities.

The use of average figures, however, conceals the fact that on occasions large differences, up to $10^{\circ} \mathrm{F}$., did exist between the readings at the metropolitan station and those at the institution. For example, on the occasion on which the highest temperature, $96^{\circ} \mathrm{F}$., was recorded at the institution, the tempera- ture at the metropolitan station was $87 \cdot 7^{\circ} \mathrm{F}$. Such ${ }^{\circ}$ discrepancies were, moreover, irregular in occurrence, but appeared to depend, at least in part, upon the direction of the prevailing wind, especially the? degree of penetration of the onshore afternoon $\overrightarrow{\vec{s}}$ breeze in summer. The use of official readings for the city of Sydney in association with the mortality at the institution could therefore, have proved $\overline{\frac{\bar{m}}{3}}$ extremely misleading.

\section{The Population Studied}

The mean population of the institution calculated $\overrightarrow{0}$ on a daily basis for the entire year was 1,467 andthis, as Table II shows, did not differ greatly fromw month to month throughout the year. The coeffi $\frac{-}{\infty}$ cient of variation between monthly mean values? was 1.54 per cent., and the range was from 1,421 i (September) to 1,494 (April). The population also tended to remain stable during any one month. Thegreatest variability occurred in August (coefficient of ${ }_{0}$ variation 1.27 per cent.) and the least in November? (coefficient of variation 0.43 per cent.). Although $_{C}$ there is no obvious seasonal variation, the number of inmates was somewhat less in the second than in the first half of the year, but any bias with respect to the population at risk for a given temperature whigh $\overrightarrow{0}$ might result from this is reduced by the occurrence@f similar temperatures in spring and autumn.

TABLE II

MEAN DAILY POPULATION OF THE INSTITUTION SHOWING VARIATION WITHIN EACH MONTH AND FROM음

\begin{tabular}{|c|c|c|c|c|}
\hline Month & $\begin{array}{c}\text { No. of } \\
\text { Inmates }\end{array}$ & $\begin{array}{l}\text { Percentage } \\
\text { of Annual } \\
\text { Mean }\end{array}$ & $\begin{array}{l}\text { Standard } \\
\text { Deviation }\end{array}$ & $\begin{array}{c}\text { Coefficient } \\
\text { of Variation } \\
\text { (per cent.) }\end{array}$ \\
\hline $\begin{array}{l}\text { January } \\
\text { February } \\
\text { March } \\
\text { April } \\
\text { May } \\
\text { June } \\
\text { July } \\
\text { August } \\
\text { September } \\
\text { October } \\
\text { November } \\
\text { December }\end{array}$ & $\begin{array}{l}1,468 \\
1,478 \\
1,486 \\
1,494 \\
1,476 \\
1,493 \\
1,488 \\
1,460 \\
1,421 \\
1,441 \\
1,452 \\
1,452\end{array}$ & $\begin{array}{l}100 \cdot 1 \\
100 \cdot 7 \\
101 \cdot 3 \\
101 \cdot 8 \\
100 \cdot 6 \\
101 \cdot 7 \\
101 \cdot 4 \\
99 \cdot 5 \\
96 \cdot 8 \\
98 \cdot 2 \\
98 \cdot 9 \\
98 \cdot 9\end{array}$ & $\begin{array}{r}9.8 \\
7.6 \\
8.9 \\
10.8 \\
11.4 \\
12.8 \\
7.7 \\
18.6 \\
10.9 \\
7.2 \\
6.3 \\
8.5\end{array}$ & 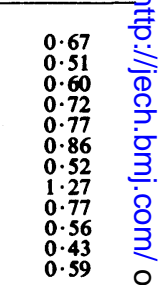 \\
\hline $\begin{array}{c}\text { Mean } \\
\text { (Jan.-Dec.) }\end{array}$ & 1,467 & & $22 \cdot 6^{*}$ & $1.54^{*} \frac{7}{\frac{D}{2}}$ \\
\hline
\end{tabular}

* Mean monthly values.

\section{Number OF Deaths}

In the 365 days considered, there were 507 deaths at the institution, a mean value of 1.39 deaths pero day. The mean age at death was 76.2 years and the distribution of the deaths with age is shown in Table III (opposite). It will be seen that only five deaths? occurred at ages less than 50 years. 
TABLE III

DISTRIBUTION OF DEATHS, BY AGE

\begin{tabular}{c|c}
\hline Age (yrs) & No. of Deaths \\
\hline $20-29$ & 1 \\
$30-39$ & 0 \\
$40-49$ & 4 \\
$50-59$ & 19 \\
$60-69$ & 78 \\
$70-79$ & 204 \\
$80-89$ & 175 \\
$90-99$ & 25 \\
\hline Total & $506 *$ \\
\hline
\end{tabular}

* The age of one patient was unknown.

\section{Effect of Daily AIr Temperature}

The distribution of deaths according to the $3.0 \mathrm{p} . \mathrm{m}$. temperature on the day on which death occurred is set out in Table IV. As temperatures below $50^{\circ} \mathrm{F}$. and above $89^{\circ} \mathrm{F}$. occurred on only 6 and 9 days respectively, these have been omitted from the Table. The most striking feature of the distribution is the occurrence of an optimum (in the sense that the number of deaths is least) temperature interval. As the temperature rises, the number of deaths decreases to a minimum in the temperature interval $70-79^{\circ} \mathrm{F}$. and thereafter rises sharply again so that the temperature interval $80-89^{\circ} \mathrm{F}$. is almost as unfavourable as the interval $50-59^{\circ} \mathrm{F}$.

TABLE IV

DISTRIBUTION OF MEAN NUMBER OF DEATHS PER DAY, BY 3.0 P.M. TEMPERATURE ON DAY OF DEATH

\begin{tabular}{c|c|c|c}
\hline $\begin{array}{c}\text { Air Temperature } \\
\left({ }^{\circ} \mathrm{F} .\right)\end{array}$ & $\begin{array}{c}\text { No. of } \\
\text { Days }\end{array}$ & $\begin{array}{c}\text { No. of } \\
\text { Deaths }\end{array}$ & $\begin{array}{c}\text { Mean No. of } \\
\text { Deaths per Day }\end{array}$ \\
\hline $50-59^{\circ}$ & 68 & 112 & 1.65 \\
$60-69^{\circ}$ & 119 & 152 & 1.28 \\
$70-79^{\circ}$ & 91 & 108 & 1.19 \\
$80-89^{\circ}$ & 72 & 113 & 1.57 \\
\hline
\end{tabular}

EFFECT of Age

The mean number of deaths per day for each temperature interval was calculated separately for each age group (classified by decades) and expressed as the percentage deviation from the mean number of deaths per day throughout the year for the age group in question. The results are shown in Table V.

In all age groups the death rate on the coldest days $\left(50-59^{\circ} \mathrm{F}\right.$.) is greater than the mean annual death rate by an amount varying from 7 to 69 per cent., but apart from this the age groups differ considerably in their response to the prevailing temperature. In the 60-69 year age group, the youngest age group in which a substantial number of deaths occurred (Table III), there appears to be no systematic effect of temperature on daily mortality. In the 70-79 year age group the extremes of temperature are both unfavourable but the temperature intervals $60-69^{\circ} \mathrm{F}$. and $70-79^{\circ} \mathrm{F}$. appear almost
TABLE V

DISTRIBUTION OF MEAN NUMBER OF DEATHS PER DAY, BY 3.0 P.M. TEMPERATURE, FOR EACH AGE GROUP SEPARATELY

Expressed as the deviation (per cent.) from the yearly mean daily death rate for each age group.

\begin{tabular}{c|c|c|c|c}
\hline \multirow{2}{*}{$\begin{array}{c}\text { Age at } \\
\text { Death } \\
\text { (yrs) }\end{array}$} & \multicolumn{3}{|c}{ Temperature at 3.0 p.m. ( } \\
\cline { 2 - 4 } & $50-59^{\circ}$ & $60-69^{\circ}$ & $70-79^{\circ}$ & $80-89^{\circ}$ \\
\hline $50-59$ & 69 & -52 & -37 & 86 \\
$60-69$ & 17 & -14 & 18 & -15 \\
$70-79$ & 21 & -14 & -13 & 19 \\
$80-89$ & 14 & 0 & -20 & 7 \\
$90-99$ & 7 & 23 & -52 & 42 \\
\hline All Ages & 19 & -8 & -14 & 13 \\
\hline
\end{tabular}

equally favourable. In the 80-89 year age group the comparatively warm temperature interval, $70-79^{\circ} \mathrm{F}$., is associated with a marked reduction in mortality and is clearly the most favourable temperature interval. In the 90-99 year age group, the decrease in mortality is even more marked in the interval $70-79^{\circ} \mathrm{F}$. and any departure from this temperature range sharply increases the mortality rate. The number of deaths in this age group is, however, small (Table III).

It would seem, therefore, that from the age of $\mathbf{7 0}$ years onwards, there is a progressive decrease in the ability to adjust to changes in environmental temperature. The 50-59 year age group is anomalous in that they resemble the much older 70-79 year age group in their intolerance of extremes of temperature. There are two possible explanations. It could be a chance effect as the number of deaths in this age group was small (Table III) or it could be due to some special characteristic of this age group in the institution concerned. It seems unlikely that it is typical of this age group in general.

\section{Effect of Preceding Days}

The effect on the death rate on any day (Day N) of the temperature prevailing on the day preceding

TABLE VI

EFFECT OF TEMPERATURE ON DAY N-1 (DAY PRECEDING DEATH) ON DEATH RATE ON DAY N (DAY OF DEATH) FOR ALL AGES

Expressed as the percentage deviation from the yearly mean daily death rate.

\begin{tabular}{c|c|c|c|c|c}
\hline \multirow{2}{*}{$\begin{array}{c}\text { Temperature } \\
\text { on Day N } \\
\text { ('F.) }\end{array}$} & \multicolumn{3}{|c|}{ Temperature on Day N-1 ('F.) } & All \\
\cline { 2 - 5 } & $50-59^{\circ}$ & $60-69^{\circ}$ & $70-79^{\circ}$ & $80-89^{\circ}$ & \\
\hline $50-59^{\circ}$ & 12 & 23 & & & 19 \\
\hline $60-69^{\circ}$ & 29 & -11 & -24 & $(-57)^{*}$ & -8 \\
\hline $70-79^{\circ}$ & & -18 & -13 & -15 & -14 \\
\hline $80-89^{\circ}$ & & $(92) \dagger$ & 6 & 19 & 13 \\
\hline \multicolumn{6}{|c|}{$\begin{array}{c}\text { Based on only 3 days' information. } \\
\text { Based on only 5 days' information. }\end{array}$} \\
\hline
\end{tabular}


death (Day N-1) was examined and the results are set out in Table VI in terms of percentage deviation from the yearly mean for all ages. Each value given in the Table has been determined from at least 17 days of information except that eight deaths in 3 days and three deaths in 5 days have been used for the calculation of the combinations $60-69^{\circ} \mathrm{F}$. (Day $\mathrm{N}$ ), 80-89 ${ }^{\circ} \mathrm{F}$. (Day N-1) and $80-89^{\circ} \mathrm{F}$. (Day N), 60-69 ${ }^{\circ} \mathrm{F}$. (Day N-1), respectively. These two combinations were included in an effort to provide some information on differences up to $20^{\circ} \mathrm{F}$. between consecutive days.

The results show that the mortality on a day on which the temperature is $50-59^{\circ} \mathrm{F}$. is higher if the preceding day has been warmer than if it has been a similar cold day. On the other hand, the mortality on a day on which the temperature is $60-69^{\circ} \mathrm{F}$. is highest when the preceding day has been somewhat colder. On days in the $70-79^{\circ} \mathrm{F}$. interval, the mortality appears to be unaffected by the temperature of the preceding day. On hot days, when the temperature is $80-89^{\circ} \mathrm{F}$, the mortality is much higher if the preceding day has also been hot. Any interpretation of these findings can only be speculative, except that it would seem reasonably clear that the effects of hot days are cumulative.

The effect of the temperature on Day N-2 on the number of deaths occurring on Day $\mathbf{N}$ was also examined, but because the temperature of the intervening day (Day N-1), which itself affects the number of deaths on Day N, varied widely, the results proved of little value.

\section{Assessment of the Effect of Temperature ON MORTALITY}

If it can be assumed that the mean daily death rate for the whole year (1.39 deaths per day) is the number of deaths to be expected on any one day if the effect of temperature is removed, then it would follow that the total number of deaths in excess of the expected number on days with an unfavourable temperature (which will be equal to the number of deaths which failed to occur on days with a favourable temperature) would provide a measure of the effect of temperature. On this basis it can be said that, for all age groups combined, unfavourable temperatures played some part in 32 deaths, that is 6.3 per cent. of the annual total.

It would seem, therefore, that for the population studied and for the relatively mild climatic conditions experienced the effect of temperature was not great. Nevertheless, in special circumstances, such as extremes of temperature or extreme age, it could well be much greater. For example, the corresponding estimate was 12 per cent. for the 90-99 year age group.
Discussion

Perhaps the most notable study of the effect of weather on mortality was that made for the city of New York under the auspices of the National? Research Council. In the report of this investigation $\underset{\overrightarrow{5}}{\overrightarrow{5}}$ (Huntington, 1930), it is stated that, when planning the undertaking in 1921, it was considered that "the first essential was a good record of daily [author's $\frac{\bar{\sigma}}{\bar{c}}$ italics] deaths in a large city". As daily records for $\overline{\mathbb{\Phi}}$ New York were at that time available only for the $\varrho$ years 1876 to 1888 , the years 1882 to 1888 were chosen for examination, despite the long period of $\overrightarrow{0}$ time which had elapsed. It is now generally agreed that daily records of deaths are essential (Gordon $\vec{\omega}$ and Erhardt, 1958) and, indeed, these are now available for New York. In consequence, a recent $\stackrel{\mathcal{Q}}{\mathcal{S}}$ examination of the effect of weather on mortality in that city (Kutschenreuter, 1959) has been able to.show that mortality is significantly higher on days $\vec{v}$ with a pronounced frontal passage.

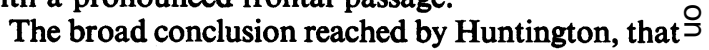
there is an optimum temperature to minimize mort- $\vec{c}$ ality, is confirmed by the present study. This he considered to be $65^{\circ} \mathrm{F}$. for high relative humidities, rising to $70^{\circ} \mathrm{F}$. at a relative humidity of 50 per cent. and presumably still higher at lower humidities. $\overrightarrow{0}$ Care must be taken, however, not to attribute too much significance to the exact temperature values these refer only to the population studied. The valuoso determined in the present investigation, for example that the lowest mortality occurs in the temperature interval $70-79^{\circ} \mathrm{F}$., have in fact been shown to apply $\frac{\mathrm{O}}{\mathrm{D}}$ only to a population of elderly men in bed or taking $\cong$ a minimum of exercise and living in an institution the $\overrightarrow{0}$ temperature of which is not substantially modified 3 by artificial means such as air conditioning or winter? heating, and who have, on the whole, been exposed? to a similar climate for many years.

However, it seems pertinent to observe that thermal $\stackrel{\rho}{\varsigma}$ comfort studies have established (Hindmarsh and Macpherson, 1962) that, in Sydney, the preferred. temperature for those conventionally clad and en-oํㅡㅁ gaged in sedentary occupations is $73^{\circ} \mathrm{F}$. In proportion, as this temperature is departed from, so does윽 discomfort from either heat or cold increase. There $>$ is thus a good measure of agreement between the estimate of the optimum temperature derived from the subjective impressions of thermal comfort in the $\mathrm{e}^{\mathrm{J}}$ young and fit and that derived from the objective $N$ event of survival in the elderly sick.

\section{SUMMary}

In an institution for the aged and chronically ill. the mortality for all ages was least (14 per cent. $\stackrel{\text { ? }}{+}$ below the annual daily average) when the 3.0 p.m. 
temperature was 70 to $79^{\circ} \mathrm{F}$. At $50-59^{\circ} \mathrm{F}$. deaths were 19 per cent. above and at $80-89^{\circ} \mathrm{F} .13$ per cent. above the annual daily average. The effect of successive hot days appeared to be cumulative. The effect of temperature first became plainly evident at 70 years of age and increased thereafter with increasing age. In the relatively mild climatic conditions prevailing, the effect of unfavourable temperatures was small, possibly having some part in 6.3 per cent. of all deaths.

This investigation was conducted under the auspices of the Unit of Clinical Investigation, Lidcombe Hospital. It is a pleasant duty to acknowledge the co-operation of the Medical Superintendent and his staff, the technical assistance of Mr G. Tormay and Mr A. Brock, and substantial help from the Commonwealth Bureau of Meteorology. This paper is published with the permission of the New South Wales Department of Public Health and the Commonwealth Director of Health.

\section{REFERENCES}

Gordon, J. E., and Erhardt, C. L. (1958). Amer. J. med. Sci., 236, 383.

Hindmarsh, M. E., and Macpherson, R. K. (1962). Aust. J. Sci., 24, 335 .

Huntington, E. (1930). "Weather and Health: A Study of Daily Mortality in New York City", Bull. nat. Res. Coun. (Wash.), No. 75.

Kutschenreuter, P. H. (1959). Trans. N. Y. Acad. Sci., ser. 2, 22, 126.

Logan, W. P. D. (1953). Lancet, $1,336$.

Russell, W. T. (1924). Ibid., 2, 335. (1926). Ibid., 2, 1128. 